\title{
SUSTAINABILITY, GLOBALIZATION, CULTURE AND WORK
}

João Almeida Santos Universidade Metodista de São Paulo, Brazil Universidade Adventista de São Paulo, Brazil

E-mail: professoralmeida@ig.com.br

Getulio Kazue Akabane Universidade Anhanguera, Brazil E-mail: getulio@akabane.adm.br

Eduardo Biagi Almeida Santos Universidade Nove de Julho, Brazil E-mail: eduardo-biagi@hotmail.com

Submission: $31 / 07 / 2013$

Revision: 15/08/2013

Accept: 16/08/2013

\section{M们绝}

\section{ABSTRACT}

This paper discusses the development process and the influence of globalization on culture and behavior of society seen on reflexes in the consumer market and how they participate or interfere in sustainability. Whereas globalization as a process of interaction between people in general originated in trade and political relations, reflections on the culture and behavior of society are inevitable from the point of view of consumption of products that are offered for new consumers in these markets that are in the process of globalization. Considering this necessity, it is important to consider the sustainable use of resources and by-products. This article is a reflection on sustainability, globalization, culture and work, and can be summarized in: a) identifying the consequences of globalization on employment from the use of technology, b) the consequences of globalization on culture are positive or negative for both involved, c) benefits globalization and society have with new, better and cheaper products to meet the population needs and d) how sustainability is in this consumingproducing context.

Keywords: Sustainability - Globalization - Culture - Society - Work 
DOI: 10.14807/ijmp.v4i2.113

\section{INTRODUCTION}

Globalization, Culture and society are concepts closely interlinked by many characteristics and can be interpreted by different point of view by the researchers. To avoid that this concepts are overviewed by political and economic sides, or an analyses of radical sustainability, this paper proposes an initial treatment of the concepts individual and the relation between them, such that the conclusion of this paper shows that globalization is associated with the culture of a people, and the society behavior can generate a consumption behavior associated with sustainability.

When these concepts are related to sustainability, the debate can take diffused proportions without this contextualization. With regard to what this article suggests - a reflection on Sustainability, Globalization, Culture and Work - the confluence of consumer markets and culture, as well as other concepts are interconnected with most relationships that can be analyzed. Globalization, Culture and Work become clearer when globalization comes with the products circulating in various markets giving the impression that they are looking for an adaptation wherever that product is accepted. The culture appears in full acceptance of how the product is being offered or adapting to the consumer behavior of this new market. And finally, in the logic of the presentation of the three concepts in the process of confluence, the society may be required to take on a new pattern of behavior by creating laws that permit the acceptance of the new product in the consumption sphere of this consumer.

Sustainability comes most recently as an apocalyptic vision made by some, and by others as an opportunity for enrichment with cheap products made basically of recycled material and having as the great motto of consumption the slogan: This product is made of recycled material.

China, as well as the entire region of East Asia, South Korea and India are appointed by Jeffrey Sachs as a successful example of globalization, since it brings together the key factors for sustainable inclusion in the globalized world (SACHS, 2002). So, it can be inferred that the countries he mentioned are lenient with the new culture and society has adapted to receive the entire volume of investment, technology and the greater possibility of generating employment and income for a large contingent of unemployed and hopeless people. India and Korea had their transformation economically focused on strong investment in technology and their 
DOI: 10.14807/ijmp.v4i2.113

capacity to change people's behavior is evident, especially when we consider the interaction existing on social networks such as Facebook and Twitter. The technologies have radically changed not only the temporal but also the spatial dimension of social reproduction (DOWBOR, 1998, p.1).

The 1980s represented a crucial moment in the evolution of the world economy, marked by three distinct phases: 1) 1979-1982 permeated by economic crises and recessions and culminating with the economic depression between 1979 and 1982; 2) 1983-1987 with economic recovery promoted by the increased U.S. demand and 3) begins in October 1987 with the crash of the stock market and international financial market with the disappearance of $\$ 1$ trillion from global economy, and goes to market adjustment in mid-1990 with greater control of currency in circulation in the world (SANTOS, 1994, p.79).

The globalized market have simultaneous reflections based on good or bad news, like a domino effect due to the strong integration offered by information technology and speed with which this information circulates around the planet. Economies like the Brazilian one saw a rapid evolution in the more advanced urban centers, although Miranda (2000, p. 78) pointed out that if Brazil wanted to have a strong information society, it should accelerate the deployment of a robust telecommunications platform so that the social interest content could be widespread in education, health, environment, agriculture, industry and trade, because such areas would provide high social returns.

In this sense, all the actors involved in the economic growth of a country must work in synergy so that the result converges into social welfare. Then:

a) Economic growth is important for maintaining the health of society in terms of moving wealth, employment generation, products and strengthening the country's geopolitical scenario;

b) The range of products shows the strength of the economy in relation to the use of new technologies and application of knowledge;

c) Government participation is important as a director and liaison between social needs and the role developed or what and how companies should do;

d) It also plays a key role in fostering resources for investment in various areas of social need such as health, education, and infrastructure. 
ISSN: 2236-269X

DOI: 10.14807/ijmp.v4i2.113

\section{METODOLOGY}

This article is a reflection on sustainability, globalization, culture and work, with the objective to identify four points: a) the consequences of globalization on employment from the use of technology, b) the consequences of globalization on culture are positive or negative for both involved, c) benefits globalization and society have with new, better and cheaper products to meet the population needs and d) how sustainability is in this consuming-producing context.

\subsection{Globalization}

Globalization is not a new phenomenon presented by recent literature. The emphasis given by authors, who only perceive its existence in the more recent context, is strongly associated with trade and movement of people. Santos (1994, p.86) believes that all regions of the contemporary world go through processes of integration to a greater or lesser extent, between their constituents and with other regions of the world, especially the United States and Europe that still represent the center of the world economy.

Globalization is a dominant trend at the end of this century (DOWBOR, 1998, p.2). It is an example of financial speculation with volumes of movement unthinkable for ordinary citizens; it is stronger than we imagine when we place this phenomenon nowadays (2012) provided by the tight integration of financial markets in the world that do not seem to have respect to what day and night is and, specially, to resting periods for their operators.

To identify the source of Globalization we start from any historical event that describes the search for new markets and regions that give power to those who were seeking to strengthen their names by conquering new peoples. It is not different today, when companies seek markets to settle in an internationalization process that can represent more power and wealth for their shareholders.

In the words of Hugon (1959, p.37):

From the twelfth to the eighth centuries before our era [as the narrative starts before Christ, the dates are in descending order], Greece only knew a domestic life. But after this time, called 'Homeric' in the classical period of the fifth century and even more so in the era of Hellenistic in the fourth and third centuries $B C$, there is the development of a proper economic life, ie an economic life of exchanges. 
DOI: 10.14807/ijmp.v4i2.113

By this excerpt it is possible to see that while there was no interaction with other peoples through trade or by invasion and enslavement, Globalization was not perceived, because it was a purely regional behavior, from where the Greeks took everything they needed to their survival without knowing other regions or markets.

The poverty of the soil, the small size of the territory and the overpopulation make trading necessary (HUGON, 1959, p.37) and the sea, with its numerous gulfs and bays, seemed to give clues to the Greeks that they had to leave in search of new territories to increase the chances of survival.

Trade with other people was a matter of survival for the Greeks and, similarly, companies seek new markets because the consumption is limited in the region where they operate or the population may have become poorer, reducing its volume of spending, imposing a limit on the length of survival of this company.

Unlike the behavior of ancient peoples who invaded territories and these were taken on the basis of physical violence and annihilation of the ones who heroically tried to resist the invasion, companies found in internationalization a way to enter the new market and, with its financial strength, seize this new market. With Globalization the production decisions and international trade were closely intertwined and most products that are traded have its origins in markets other than the local, or most of its components are produced or depend on other market (SILBER, 2010, p. 17).

Table 1: Growth of GDP and world trade volume (\%)

\begin{tabular}{c|c|c|c|c|c|c|c}
\hline & $1953 / 1973$ & $\mathbf{1 9 7 3 / 1 9 8 0}$ & $\mathbf{1 9 8 0 / 1 9 8 5}$ & $\mathbf{1 9 8 6 / 1 9 9 0}$ & $\mathbf{1 9 9 1 / 2 0 0 0}$ & $\mathbf{2 0 0 1 / 2 0 0 3}$ & $\mathbf{2 0 0 4 / 2 0 0 6}$ \\
\hline $\begin{array}{c}\text { World } \\
\text { Trade }\end{array}$ & 7,8 & 4,6 & 3,4 & 5,2 & 7,7 & 2,3 & 8,3 \\
\hline $\begin{array}{c}\text { World } \\
\text { GDP }\end{array}$ & 4,8 & 3,3 & 3,3 & 3,4 & 3,5 & 2,9 & 4,7 \\
\hline
\end{tabular}

Source: adapted by the authors based on Silber, 2010, p.18

In the period from 1953 to 1973 , world trade is growing because of the implementation of recovering policies of post-World War II captained by the U.S. with a global trade growth of $7.8 \%$ as shown in table 1 . After this period of large growth data show a slight decline between 1980 and 1985 and again a period of decline between 2001 and 2003, 3.4\% and 2.3\% respectively. The increase in interest rates imposed by the U.S. forced the underdeveloped countries (later called "on development" and today "emerging") to pick up loans to pay old bills and interest, 
creating a snowball of extracting financial resources from the Third World (SANTOS 1994, p. 78/9).

Evaluations of the 1987 crisis and the 1998 Asian imbalances allow a critical view of this process watered by large volumes of volatile cash. Flows have become global, while the regulatory instruments continue under the national State (DOWBOR, 1998, p. 2). From the historical point of view globalization starts as a matter of survival for peoples lacking land to plant and harvest what they needed, representing their only wealth. The world evolves and moves toward a commercial globalization of production with the invasion of transnational capital in the late nineteenth and early twentieth centuries, when companies settled for producing goods for those people and create wealth for themselves. It advances to the political globalization by providing large loans and exchanges of technology or infrastructure products such as those in the energy sector with nuclear power in mid-1970, mainly in Brazil, and reaches today with financial globalization and capital flowing through the markets of different countries of the world at the speed that the information technology allows.

Globalization, which is a process of trade integration and intensive production systems among various countries of the world and trade involving all kinds of goods and services, still keeps its earliest definition and its origin from the commercial and productive point of view. The changes are focused on the importance given to the product and currency that suffers speculation and increase its power in the intensity of these speculations and the force exerted by experts in destroying markets and economies without producing goods for the survival of society where they are acting.

\subsection{Culture}

Culture is a dynamic phenomenon that follows us all the time, being constantly performed and created by our interactions with others and shaped by leadership behavior, and a set of structures, routines and norms that guide and constrain behavior (SCHEIN, 2009, p.1). Since the 1980s, companies became objects of cultural analysis, because there were many notions of culture. Then, what remained was that culture is a set of values and meanings that provide a shared common basis (BARBOSA org., 2009, p.1). 
Culture is an abstraction, even though the forces that are created in social and organizational situations that derive from it are powerful (SCHEIN, 2009, p.3). The origins of Brazilian culture formed by the indian, Portuguese and black African, give the dimension of power derived from the breakdown of Brazilian culture due to the poor cultural roots. Then the central countries considered developed and owners of capital and culture choke Brazilian culture under the pretext that it failed to form roots and is bound to run out an identity although this has changed with the economic opening in mid-1990 (TANURE in BARBOSA org., 2009, p.30).

Culture is a sociological and anthropological concept that involves multiple definitions. For some, culture is the way with which a community meets their material and psychosocial needs (MOTTA, 2011, p.16).

\subsection{Globalization and culture of organizations}

The term Organizational Culture was first discussed in Brazil in the 1980s and Brazilian Culture has sought its own identity (MOTTA, 2011, p.30). Culture is a dynamic phenomenon that follows us everywhere, being constantly performed and created by our interactions with others and shaped by leadership behavior, and a set of structures, routines and norms that guide and constrain behavior (SCHEIN, 2009, p.1).

Following the line of thought established by table 2, Brazilian organizations are importing models because they do not identify their origin, since all three arrays of Brazilian culture as indian, Portuguese and black African are broken by the little that is known, especially indians and black Africans. The first groups of this matrix - the indigenous - best known are: Tupi-Guaranis, Tapuias, Nuaruaques and Caraibas. The third - black Africa - were basically from two ethnic and cultural frameworks: Bantu and Sudanese, their cultures being much closer to the Portuguese than the indigenous culture (MOTTA, 2001, p.17).

However, the big question that remains is the way in which the behavior of organizations varies culturally (MOTTA, 2001, p.25). The management style tends to consider which approach mentioned in table 2 ? Or, culture must necessarily be associated with leadership, because we see two sides of the same coin, neither one nor the other can actually be understood by itself (SCHEIN, 2009, p.10). 
Table 2: Three approaches to the Influences of the culture of the country in corporate management

\begin{tabular}{l|l}
\hline Approach & Key Features \\
\hline Convergent (universal) & $\begin{array}{l}- \text { propagated by the academy until the 1970s and with the } \\
\text { globalization phenomenon has recently been resumed, especially } \\
\text { in multinationals; } \\
- \text { There is only one acceptable way to manage; } \\
- \text { When companies such as retailer Marks \& Spencer began } \\
\text { operations in France and Belgium moved in totum their practices, } \\
\text { such as plastic bags used in Britain: "Buy in British stores, keep } \\
\text { British jobs!" }\end{array}$ \\
\hline Divergent (Relativistic) & $\begin{array}{l}\text { - Users: Whitfield and Poole (1997), Godard and Delaney (2000), } \\
\text { Clark and Mallory (1996) } \\
\text { - Emphasized in 1970 driven by classical studies such as Hofstede, } \\
\text { which demonstrated the impact of a country in the management }\end{array}$ \\
\hline Convergent Divergence & $\begin{array}{l}- \text { The Western logic is exclusive, while the Eastern logic tends to be } \\
\text { inclusive } \\
- \text { Cultural bias in this statement is in the globalization and impact of } \\
\text { advances in information technology that expand the frontiers of } \\
\text { communication }\end{array}$
\end{tabular}

Source: prepared by the authors with data from Tanure (in Barbosa org., 2009, p.31/2)

\subsection{Globalization, technology and employment}

Globalization is an integration process between the countries of the world who engage in an exchange in quantity and diversity of product, being difficult to imagine a world without globalization (KRUGMAN, 2002). Globalization is not general and when we look at our daily life, the house where we live, the school, the doctor for our family, the workplace, the products we consume and other things that are within our reach, we realize that nothing is global (DOWBOR, 1998, p.3). The products may have been made in another country, but our relations are local. There was a change in the production process and how companies produce, requiring an adjustment of employment and new knowledge so that the individual could continue employed and taking from their workforce the wage to provide for their needs.

With the evolution and increasingly frequent use of technology people are forced to adapt quickly to continue being useful to society. New knowledge and preparation to assume positions in an increasingly global market and of cultural change imposed by the production process from different origins of the way of life of the citizen is the result of a representation of a standardized global production in order to reduce time and mostly costs. Miranda (2000, p.79) considers that this situation has been accentuated mainly because the capitalist industrial production mode became hegemonic in the production and distribution of intellectual products 
DOI: 10.14807/ijmp.v4i2.113

and through its distribution mechanisms - those of media in general - interfere powerfully in the economic, political and cultural processes of societies.

\subsection{Future of work}

The changes arising from greater commercial interaction between countries termed as globalization generate profound changes in the production process and the behavior of people towards the new production process that increasingly uses technology with new machinery and equipment that produce staggering volumes of goods for consumption, which society does not necessarily consume in the same speed. With this new behavior it is necessary to adapt the organization of work that must leave the industrial production to favor the production mode based on information technology (MEIRA, 2010).

Digital information widely available almost worldwide allows to review the form of work organization and the city, whose origins and forms of behavior goes back the last hundred and fifty years (MEIRA, 2010). A new stage of development of the productive forces, whose nature is characterized by a techno-scientific revolution, the fundamental laws are grounded in substitution of directly productive labor and the natural division of labor by machinery, machine systems, power plants, industrial complexes and increasingly complex production systems that connect other systems relatively autonomous (SANTOS, 1994, p.83).

The current context of work is increasingly farther than Adam Smith pointed out in his study saying that the work was a source of wealth, unlike the mercantilists, who believed that gold and silver as a source of wealth and the Physiocrats, the land (HUGON, 1959, p.131). The concentration and centralization of production, which characterized the industrial revolution, assume a global and planetary form, yielding productive complexes of international and transnational nature (SANTOS, 1994, p.83).

The way we work has changed by the advent of new technologies and increased global demand of the last twenty years. This has influenced the behavior of people who find themselves closer to the consumer with the opportunities provided by financial market participants and their offers of easy credit to a consumer increasingly ephemeral. To verify the necessity of more production it is necessary to understand that the population increases year by year, even if at a slower pace of 
DOI: 10.14807/ijmp.v4i2.113

growth, and this also requires increased production, variety of products based on their application and needs, which change in the same way the life style changes.

An issue as important as globalization and work is in the culture in terms of behavior, the way people are; as defined by Schein (2009, p.3): Culture is an abstraction, even though the forces that are created in social and organizational situations which derive from it are powerful; ie people change their behavior and global products contribute to it, the same way that information technology allows to access information behavior and the way of life of people who are miles away.

Among the various behaviors that we have access are the offices that represent true dreams of consumption, since they present a layout very close to a playground and not the conventional work office, or people working from home as if they were living an eternal pleasure. This working model has no place in many organizational cultures such as the Brazilian or space in their homes in order to have a home office.

For work to be done at home people will have to go through a learning behavior in order to face the situation as described by Meira (2010) as the smell of food in the house, size of the apartments; the psychological issue being more relevant than the actual physical barrier.

\subsection{Culture and organizations in brazil}

Brazil is considered a collectivist society, although not the most collectivist. Motta quotes Hofstede to support the argument that Japan is a collectivist country par excellence and believes that in Brazil the distance of power is too big, losing to other societies of Latin America except Argentina (MOTTA, 2001, p.30).

Considering the definition of Hofstede: culture is the way a human group thinks, feels and reacts, mainly received and transmitted by symbols; Brazilian organizations received the learning from the Portuguese and foreign companies that have settled here with their culture and way of doing things.

The colonization model started and inherited by the Portuguese, made Brazilian organizations with a high degree of dependence on decision making and especially easy and interest free resources. The colonization based on exploitation and actions of people who were not interested in contributing to the local progress except for their own, fast benefit, made the exploration model imperative from culture 
to culture, i.e. from the period of planting sugar cane to coffee or cocoa, rubber, and other others.

If, instead of adopting the model of colonization by exploitation - depleting the dominant wealth resource at the time - the model of colonization by settlement was adopted - the one in which people remain on the land and grow from their knowledge - as was the case in the U.S., where a number of immigrants who could not return home had to work and invest all their knowledge to turn new land into their new home. The Brazilian economy would have another behavior profile and the organizations would copy this culture model, as described in table 1, particularly in the divergent approach (relativistic).

\subsection{Sustainability}

Sustainability is a concept widely used now with a strong association with preserving the environment. Concerns about preserving the planet and the rational use of its resources have given rise to indiscriminate use of the concept. Another concept that has been widely used is: sustainable development, also with the connotation of preserving the environment. Sustainability can mean the support given to something, allowing it to live eternally without the help of others or resurface every time a portion of existing resources is used. In this sense, the concept sustainability can have a strong relationship with the preservation or something you want to renew each time a part is extracted. From the conceptual point of view, sustainable development seems to be one of the most important social movements of this century and the beginning of the millennium, going from initiatives of individuals in search of cleaner air to breathe to businesses and governments, some with initiatives more serious and others less serious, but all wanting a better planet to live (BARBIERI et. all., 1991).

Sustainability of a business is when it generates its own revenues, enough to keep the company in operation and to keep the interest of the owner or investors. Combining this concept with the planet, the resources that will be extracted for the production need to be replaced by the same amount so that the process of production and consumption happen in a natural way to meet the needs of society. When resources are damaged so that they cannot be renewed, the production process should be analyzed, looking into which elements are being employed and 
DOI: 10.14807/ijmp.v4i2.113

which are damaging the environment so that alternatives can be found for its preservation.

Economic growth was a proposal made to society as a way to promote the welfare of all, i.e. better health, more food, more schools, changes that ultimately could generate more comfort. This was done based on inflow of more capital, more privatization, more production, liberalization of the economy so that the movement of capital was widespread, and innovation in production processes and the relationship between government and population. This was an urgent need for society that life would improve with more jobs and income, output and product variety (KLIKSBERG.2008).

\section{FINAL CONSIDERATIONS}

This article brought a reflection on globalization, culture and work considering that globalization is a process of trade integration with the use of intensive production systems among various countries and trade involving all kinds of goods and services. Culture is a dynamic phenomenon that follows us all the time, constantly being performed and created by our interactions with others and shaped by leadership behavior, and a set of structures, routines and norms that guide and constrain behavior (SCHEIN, 2009, p.1). Work is all human activity that generates goods and services for society.

Taken this into account, globalization affects the culture of a people and their way of producing from work, which is also changed by production models which use technology extensively and increases the distance between the man and his own relationship. Today, with the expansion of information technology facilitating the search for information about the various cultures and with globalization, which has extended the possibility of people being able to purchase products and information from everything and everyone, organizations must change their culture and Brazilian people should gain an identity from the discovery of the definition of Brazilian culture.

The culture of Brazilian organizations should not be defined by generalizing behavior. Even considering the cultural diversity of the Brazilian people, foreign companies that have settled here attracted by promises of easy capital and transfer of profits, as promised by the first term of Getúlio Vargas's government (1930-1945) or the acceleration in economic growth imposed by the government of Juscelino 
Kubitschek (1956-1961), brought their culture and then adjusted to better fit to the needs of the Brazilian people.

Therefore, comparing the needs of an economy by generating employment and income and the ideas defended in images of organization we notice that the company needs to continue to grow in order to innovate and remain as a living organism. What we may have to discuss is how the process of growth and wealth generation should be. Whether it should be more or less ethical, more or less moral and related to what the world needs to avoid waste and environmental problems.

We must stop any process that hurts the ethics, generates further environmental problems and damage in the use of public resources. The contribution of each member of society is not to let "small acts" that look innocent be practiced and accepted as normal, because when that happens society behaves indifferently before misconduct on the part of governments, organizations and even common individuals.

\section{REFERENCES}

ALBANDES-MOREIRA, L. A. (2004) Pós-globalizacao, administração e racionalidade econômica: a síndrome do avestruz. Rev. adm. contemp. [online]., vol.8, n.4, pp. 215-217. ISSN 1982-7849.

http://www.scielo.br/pdf/rac/v8n4/v8n4a11.pdf

AMORIM, W. A. C.; FISCHER, A. L. (2009) Aprendizagem Organizacional: uma análise sobre o debate e a escolha de categorias para estudos de caso.

Perspectivas Contemporâneas, Campo Mourão, v. 4, n. 1, p. 101-125, Jan./Jun. ISSN: 1980-0193.

BARBIERI, J. C. et. al. (1991) Inovação e Sustentabilidade: novos modelos e proposições. Revista de Administração de Empresas, v. 50, n. 2, p. 146-154, doi: 10.1590/S0034-75902010000200002

BARBOSA, L. (2009). Cultura e Diferença nas Organizações. Sao Paulo: Atlas, 2009.

BARBOSA, L.; VELOSO, L. (2009) A Cultura do Outro: interculturalidade e dialogia nas empresas in Cultura e Diferença nas Organizações. Sao Paulo: Atlas, p. 161.

CAMINHA, M. (2009) A vida para o consumo: sujeitos como mercadoria. Niteroi: Revista do programa de pós-graduação em comunicação - Universidade Federal Fluminense. n. 20, agosto. p. 206. http://www.scielo.br/pdf/rsocp/n23/24633.pdf

DIAZ, L. M. (2005). Más ética, más desarrollo. Revista Convergencia. Universidad Autónoma del Estado de México. Toluca: Mexico, vol.12. num. 38. P. 413-421. http://redalyc.uaemex.mx/pdf/105/10503818.pdf

DOWBOR, L. (2010). Democracia Econômica: Alternativas de Gestão Social. Ensaio Teórico. http://dowbor.org. 
FREITAS, M. E. (2010) Cultura Organizacional: Evolução Critica. Coleção Debates de Administração. Sao Paulo: Cengage Learning.

HUGON, P. (1959). Histórias das Doutrinas econômicas. Sao Paulo: Editora Atlas S/A [atual Atlas], $5^{\mathrm{a}}$ edição.

KLIKSBERG, B. (2008) Más ética, más desarrollo. Argentina: Editora Argentina.

KRUGMAN, P. (2002). Fragmentos da globalização. Entrevista Revista HSM, 2002. http://www.hsm.com.br/artigos/fragmentos-da-globaliza\%C3\%A7\%C3\%A3o

MACHADO-DA-SILVA, C. L.; GUARIDO FILHO, E. R.; ROSSONI, L. (2006).

Campos Organizacinais: seis diferentes leituras e a perspectiva de estruturação.

RAC, Edição Especial. p. 159-196.

MEIRA, S. (2010). Os 6 Cs do futuro do trabalho. Entrevista Revista HSM.

http://www.hsm.com.br/artigos/os-6-cs-do-futuro-do-trabalho

MIRANDA, A. (2000). Sociedade da informação: globalização, identidade cultural e conteúdos. Ci. Inf., Brasília, v. 29, n. 2, p. 78-88, maio/ago.

http://www.scielo.br/pdf/ci/v29n2/a10v29n2.pdf

MOTTA, F. C. P.; CALDAS, M. P.(2011). Cultura Organizacional e Cultura Brasileira. Sao Paulo: Atlas.

PORTASL HOFSTEDE: http://www.geerthofstede.com/

SANTOS, T.(1994). Globalização e Regionalização na Economia Mundial.

Biblioteca da Universidade Federal Fluminense. Mimeo.

SCHEIN, E. H. (2009). Cultura Organizacional e Liderança. Sao Paulo: Atlas.

SILBER, S.; LIMA, M.; VASCONCELOS, M. A. S.(2010). Gestão de Negócios Internacionais. Sao Paulo: Saraiva. 